\title{
Changes in kernel chemical composition during nut development of three Italian hazelnut cultivars
}

\author{
Valerio Cristofori ${ }^{1, \star}$, Gianpaolo Bertazza ${ }^{2}$ and Cristina Bignami ${ }^{3}$ \\ 1 Dipartimento di Scienze e Tecnologie per l'Agricoltura, le Foreste, la Natura e l'Energia, Università degli Studi della Tuscia, Via S. Camillo \\ de Lellis snc, 01100 Viterbo, Italy \\ 2 Consiglio Nazionale delle Ricerche, Istituto di Biometeorologia, Sezione di Bologna, Via P. Gobetti 101, 40129 Bologna, Italy \\ 3 Dipartimento di Scienze della Vita, Università degli Studi di Modena e Reggio Emilia, Via Amendola 2, 42122 Reggio Emilia, Italy
}

Received 11 September 2014 - Accepted 31 March 2015

\begin{abstract}
Introduction. This research focused on the variation of the kernel and pellicle (seed coat) constituents during nut growth, from early development to maturity. Material and methods. Nuts of three hazelnut cultivars widely grown in Italy: 'Tonda Gentile Romana', 'Tonda di Giffoni' and 'Nocchione'. were randomly sampled weekly, from the same trees, starting from the first week of July 2007 (day of the year: DOY = 186) until the beginning of September (DOY $=249$ ), at harvest time. Results and discussion. Oil content increased continuously during the development of


September. Total monounsaturated fatty acids were the main group of fatty acids in the oil and oleic acid was the most predominant one, showing slight variations depending on the cultivar and kernel growth stage. Nitrogen content in the

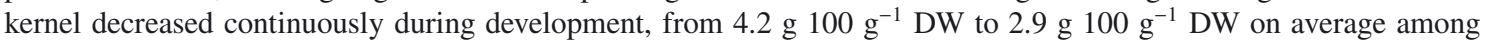
the cultivars. Soluble sugars, mainly sucrose, showed a wide fluctuation until late July, and the content observed in the

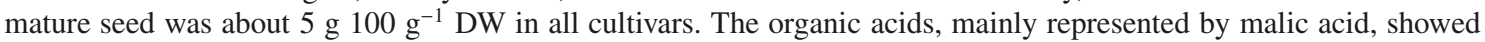

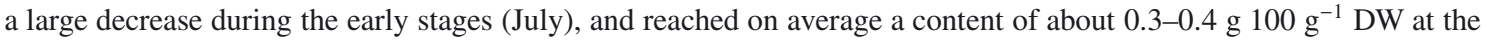
mature stage. Starch content for all cultivars was highest at the first sampling date, then decreased rapidly, coinciding with the initial kernel expansion stage. Starch levels then increased to a second peak in early August, then rapidly decreased again, followed by a gradual decline up to the time of nut ripening. The total phenol content was mainly concentrated in the pellicle and showed wide variation during the nut development both in the kernel and pellicle. Conclusion. The complexity of these dynamics can explain the different kernel taste in immature and mature states, and highlights the possibilities of optimizing the orchard management and harvesting time.
\end{abstract}

Keywords: Italy / hazelnut / Corylus avellana / nutritional value / fatty acid profile / soluble carbohydrates / organic acids / phenolics

Résumé - Changements dans la composition chimique de la noisette au cours du développement de trois cultivars italiens de noisetier. Introduction. Cette étude a porté sur la variation de la composition de la noisette et de son tégument pendant la croissance des fruits, depuis le début de leur développement jusqu'à maturité. Matériel et méthodes. Les noisettes de trois cultivars de noisetiers largement cultivés en Italie : 'Tonda Gentile Romana', 'Tonda di Giffoni' et 'Nocchione'. ont été échantillonnées au hasard chaque semaine, sur les mêmes arbres, à partir de la première semaine de juillet 2007 (jour de l'année : DOY = 186) jusqu'à début septembre (DOY = 249), à la récolte. Résultats et discussion. La teneur en huile des fruits a régulièrement augmenté au cours du développement des noisettes, de 30-35 g $100 \mathrm{~g}^{-1}$ masse sèche (MS) au début de juillet, à 61-68 g $100 \mathrm{~g}^{-1}$ MS lors de la première semaine de septembre. Les acides gras mono-insaturés étaient le principal groupe d'acides gras dans l'huile de noisette, et l'acide oléique était prédominant, montrant de légères variations selon le cultivar et le stade de croissance de la noix. La teneur en azote de la noix n'a cessé de diminuer au cours de son développement, de 4,2 à 2,9 g $100 \mathrm{~g}^{-1} \mathrm{MS}$ en moyenne pour les cultivars étudiés. Les sucres solubles, essentiellement le saccharose, ont montré une grande fluctuation jusqu'à la fin juillet, et

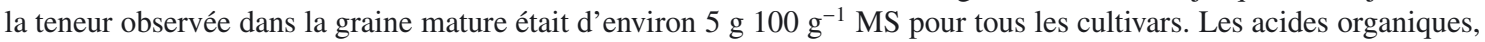
principalement représentés par l'acide malique, ont montré une baisse importante pendant les premiers stades de développement (juillet), pour atteindre une teneur moyenne de 0,3 à $0,4 \mathrm{~g} 100 \mathrm{~g}^{-1} \mathrm{MS}$ à maturité. La teneur en amidon dans tous les cultivars était le plus élevé à la première date d'échantillonnage, puis a rapidement diminué, coïncidant avec la phase initiale d'expansion de la noix. Les teneurs en amidon ont ensuite présenté un second pic au début août, puis à

\footnotetext{
^ Corresponding author: valerio75@unitus.it
} 
nouveau rapidement diminué, avec une baisse progressive jusqu'à la maturité des noix. La teneur en phénols totaux est principalement concentrée dans le tégument et a présenté de fortes variations au cours du développement à la fois dans la noix et son tégument. Conclusion. La complexité de ces dynamiques peut expliquer le goût différent de la noix aux états immature et mature et met en évidence les possibilités d'optimiser la gestion des vergers et de leur récolte.

Mots clés : Italie / noisetier / Corylus avellana / valeur nutritive / profil d'acides gras / glucides solubles / acides organiques / composés phénoliques

\section{Introduction}

Hazelnut (Corylus avellana L.) is the main nut tree grown in Italy, which is the second-largest producer country in the world behind Turkey, with about 90,000-130,000 t shell nuts per year [1]. The evaluation of nut quality is mainly based on the level of defects and on nut yield (kernel/nut ratio) [2]. In recent years, the potential for intrinsic quality has gained attention, with the aim of promoting nut consumption [3-6]. The nutritional properties of hazelnut and its health benefits, related to the richness of high-value fatty acids and natural antioxidants, have been emphasized [7,8]. Among the chemical components of the kernel, lipids are considered the factor giving a major contribution to the quality and storability of nuts and derived products $[9,10]$. Nevertheless, other minor components, such as sugars, organic acids, and phenolic and aromatic fractions, can be involved in the expression of nut taste and quality $[11,12]$.

The trend to increase the use of nuts in the food industry for a wide range of processed products and the demand for excellent organoleptic traits both justify the interest in research aimed at a better knowledge of the chemical qualitative parameters of nuts and their processed products. The limited information available on intrinsic and external factors involved in the determination of nut quality and linked with the organoleptic properties represents a further reason to start or improve this research field.

While the chemical composition of mature nuts and its dependence on genotype and geographical origin has been quite extensively analyzed [8,13-16], the variation of kernel composition during nut growth and ripening has been the subject of little research, mainly focused on the fat component $[9,17,18]$ of some Turkish cultivars [19-21] and the mineral content of new Chinese crossbreeds [22].

The analysis of minor constituents such as starch, soluble sugars, organic acids and phenolics has been long neglected. Nevertheless, their importance for the nutritional, health and sensory quality of mature seeds has been highlighted [3, 16, 23]. Recent research on hazelnut phenolics has revealed the variability of the total content and of single phenolic compound concentrations among genotypes, which can have different antioxidant capacity [24], thus supporting the interest in in-depth studies on the large number of hazelnut cultivars.

Maturity at harvest can influence the kernel quality of nuts [25]. In addition to the prevalent use of mature hazelnuts, the direct consumption of not completely ripe "green hazelnuts" needs some attention as it is a tradition in some areas [26,27]. Furthermore, studies on chemical changes during fruit development are very limited for native Italian hazelnut cultivars. Therefore, this study was planned to determine the chemical changes in main and minor components during nut development in the kernel of three round-shaped hazelnut cultivars widely grown in Italy. A further objective of the study was to identify the stage of nut development at which the pellicle, easily removable from the immature seed, has a high phenol content, in order to be used as a potentially inexpensive source of natural antioxidants and extracted by methods recently reported on the kernel and hazelnut green leafy cover [5].

\section{Materials and methods}

\subsection{Plant materials}

The trial was carried out in a mature orchard located in Viterbo province (latitude $42^{\circ} 18^{\prime} \mathrm{N}$, longitude $12^{\circ} 15^{\prime} \mathrm{E}$, altitude $350 \mathrm{~m}$ ), Latium, Italy. The soil texture was medium loam with $1.5 \%$ of organic matter and a $\mathrm{pH}$ of 5.8. The unirrigated two-hectare orchard was managed with a natural green cover crop according to the rules of the hazelnut Integrated Production System [29] and had applications of the following quantities of general fertilizers: $120 \mathrm{~kg} \mathrm{ha}^{-1} \mathrm{~N}, 60 \mathrm{~kg} \mathrm{ha}^{-1} \mathrm{P}_{2} \mathrm{O}_{5}$ and $60 \mathrm{~kg} \mathrm{ha}^{-1} \mathrm{~K}_{2} \mathrm{O}$. Three Italian cultivars producing roundshaped nuts were analyzed: the main crop varieties 'Tonda Gentile Romana' (TGR) and 'Tonda di Giffoni' (TG), and 'Nocchione' $(\mathrm{N})$, the traditional pollinizer of TGR. The orchard, 30 years old, was established with 400 trees of TGR (20 rows, 20 trees per row) and 200 trees (10 rows) of TG and $\mathrm{N}$, respectively. The trees, spaced $5 \mathrm{~m} \times 5 \mathrm{~m}$, were trained to bush form, with 3-5 stems.

Nuts were sampled weekly, at ten different times, starting from the first week of July (DOY $=186$ ), when nuts were a light green color and had a kernel/nut ratio of $25-30 \%$, until the beginning of September (DOY $=249$ ), when nuts were ripe and harvestable. Three trees per cultivar were marked in the middle of the orchard and used for subsequent sampling throughout the different stages. About $2 \mathrm{~kg}$ nuts were collected randomly from different heights of the canopy, ranging between 1.5 and $3.0 \mathrm{~m}$ from the ground, and all around the crown for each stage and cultivar, placed inside a polystyrene box with cooling gel, and then stored in the laboratory at $-20^{\circ} \mathrm{C}$ until analysis. All analyses were performed in triplicate for each sample.

\subsection{Kernel composition analysis}

Prior to kernel composition analysis, the nut and kernel weight, width, thickness and height, and shell weight were recorded on sub-samples of 50 nuts for each cultivar at each 
stage. Immediately before the analysis, sub-samples of nuts were manually cracked, shelled, and the kernels were finely crushed. A fraction of kernels were peeled by hand, using a scalpel, into a polystyrene box with ice, to obtain a sufficient quantity of kernel pellicle. The dry matter content in the kernel and pellicle was determined after drying at $103 \pm 2{ }^{\circ} \mathrm{C}$ until a constant weight was achieved.

Oil in the kernel was extracted by the Soxhlet method, using light petroleum ether (boiling point $40-60{ }^{\circ} \mathrm{C}$ ). A 10 -g portion of finely crushed kernels was placed in a cellulose thimble and extracted with $200 \mathrm{~mL}$ petroleum ether for $6 \mathrm{~h}$ in a Soxhlet apparatus. After extraction, the solvent was evaporated and the residual oil was weighed.

The total nitrogen content was determined through the Kjeldahl method using a Gerhardt digester [30]. Briefly, a 1$\mathrm{g}$ portion of finely crushed kernels was placed in a dry Kjeldahl flask ( $800 \mathrm{~mL}$ in volume), then $2 \mathrm{~g}$ of digestion mixture (composed of $\mathrm{SeO}_{2}, \mathrm{~K}_{2} \mathrm{SO}_{4}$ and $\mathrm{CuSO}_{4}$ ) was added. This sample was digested using $10 \mathrm{~mL}$ of $\mathrm{H}_{2} \mathrm{SO}_{4}(96 \% \mathrm{w} / \mathrm{v})$ at $390{ }^{\circ} \mathrm{C}$ for $3 \mathrm{~h}$, until clear digestion was obtained. The digested samples were distilled using $50 \mathrm{~mL} \mathrm{NaOH}(40 \% \mathrm{w} / \mathrm{v})$ and the liberated ammonia was collected and added to $10 \mathrm{~mL} \mathrm{H}_{3} \mathrm{BO}_{3}$ solution $(1 \% \mathrm{w} / \mathrm{v})$, in the presence of an alcohol solution of methyl red and bromocresol green (BCG) as an indicator. Finally, the liberated ammonia was titrated against $\mathrm{H}_{2} \mathrm{SO}_{4}$ $(0.1 \mathrm{~N})$ and the content in the kernel was expressed as a percentage, then calculated as g $100 \mathrm{~g}^{-1} \mathrm{DW}$.

The fatty acid composition was analyzed on lipids separated from the aqueous extract obtained in the first steps of sugar extraction [31] by adding distilled water. The purified oil was mixed with a solution of butylated hydroxytoluene (BHT) as an antioxidant in $n$-heptane $\left(5 \mathrm{mg} \mathrm{mL}^{-1}\right)$ in the ratio $1: 1(\mathrm{v} / \mathrm{v})$. A $100-\mu \mathrm{L}$ aliquot of oil was converted to methyl esters in methanol with $50 \mu \mathrm{L}$ of $0.1 \mathrm{~mol} \mathrm{~L}^{-1} \mathrm{KOH}$ and shaken for $30 \mathrm{~min}$. A $100-\mu \mathrm{L}$ aliquot of $n$-heptane was added and $0.3 \mu \mathrm{L}$ of the supernatant was injected into a gas chromatograph (GC) equipped with a flame ionization detector (FID) and a Restek Stabilwax capillary column $(30 \mathrm{~m} \times 0.5 \mathrm{~mm}$ i.d., $1.0 \mu \mathrm{m}$ film thickness; Restek Corporation, Bellefonte, PA, USA). The temperature of both the injector and detector was $260{ }^{\circ} \mathrm{C}$. The column temperature was held at $200^{\circ} \mathrm{C}$ for $3 \mathrm{~min}$, then increased at $4{ }^{\circ} \mathrm{C} \mathrm{min}-1$ to $220{ }^{\circ} \mathrm{C}$ and $6{ }^{\circ} \mathrm{C} \min ^{-1}$ to $250{ }^{\circ} \mathrm{C}$, and finally held at $250{ }^{\circ} \mathrm{C}$ for $10 \mathrm{~min}$. The retention times of the compounds were compared with those of fatty acid standards, and the percentage of the total was calculated for each compound.

Qualitative and quantitative determination of soluble sugars and organic acids was carried out by gas-liquid chromatography (GLC) according to Bartolozzi et al. [31]. A 5-g portion of finely crushed kernels was extracted in $100 \mathrm{~mL}$ of a solution of imidazole $(0.05 \mathrm{M}, \mathrm{pH} 7.2)$ and ethanol $(1: 1 \mathrm{v} / \mathrm{v})$, to which were added $\beta$-phenylglucopyranoside $(2.5 \mathrm{mg})$ as an internal standard and the antioxidant butylated hydroxyaniline (BHA). A 2-mL aliquot of the extracts was evaporated to dryness, treated with $500 \mu \mathrm{L}$ pyridine, $200 \mu \mathrm{L}$ hexamethylsilazane and $100 \mu \mathrm{L}$ trimethylchlorosilane and heated at $50{ }^{\circ} \mathrm{C}$ for $1 \mathrm{~h}$. The trimethylsilyl derivatives were injected into a Chrompack CP 9000 GC equipped with a splitter injector, a flame ionization detector and a CP-Sil-5CB capillary column
(25 m, $0.25 \mathrm{~mm}$ i.d., $0.12 \mathrm{~mm}$ film thickness) (Chrompack, Middelburg, Netherlands). The temperature of both the injector and detector was $350^{\circ} \mathrm{C}$. The column temperature was held at $120^{\circ} \mathrm{C}$ for $1 \mathrm{~min}$, then increased at $10{ }^{\circ} \mathrm{C} \mathrm{min}^{-1}$ to $180^{\circ} \mathrm{C}$, at $15^{\circ} \mathrm{C} \mathrm{min}{ }^{-1}$ to $270{ }^{\circ} \mathrm{C}$ and at $20^{\circ} \mathrm{C} \mathrm{min}^{-1}$ to $350{ }^{\circ} \mathrm{C}$, and finally held at $350{ }^{\circ} \mathrm{C}$ for $6 \mathrm{~min}$. The retention times of the standards of the main sugars and organic acids present in the nuts were used for qualitative determination.

In order to determine the starch content, a 1-g dried residual pellet of sugar extract for each sample was homogenized with $25 \mathrm{~mL}$ of $1 \mathrm{~mol} \mathrm{~L}^{-1} \mathrm{HCl}$ in a water bath at $90{ }^{\circ} \mathrm{C}$ for $4 \mathrm{~h}$ to hydrolyze the starch. The suspension was neutralized with $1 \mathrm{~mol} \mathrm{~L}^{-1} \mathrm{Na}_{2} \mathrm{CO}_{3}$, then $2 \mathrm{~mL}$ methyl mannopyranoside was added as an internal standard. The sample was centrifuged and made up to a final volume of $50 \mathrm{~mL}$ with ethanol. A $2-\mathrm{mL}$ aliquot of the extract was heated to dryness and treated as previously described for soluble sugars according to Bartolozzi et al. [31].

The total phenol content in the kernel with the pellicle and in the pellicle only was determined according to the Folin-Ciocalteu procedure [32]. A 5-g lyophilized sample was placed in a test tube with $25 \mathrm{~mL}$ of extraction solution (methanol/water, 2:1 v/v) according to Yuritas et al. [33]. The mixture was placed in the dark at $4{ }^{\circ} \mathrm{C}$ for $24 \mathrm{~h}$. The supernatant was collected and replaced with an equal volume of extraction solution. The two supernatants were mixed and extraction solution was added until a total volume of $50 \mathrm{~mL}$ was obtained. A 2-mL aliquot of extraction solution was mixed with $10 \mathrm{~mL}$ of 1:10 diluted Folin-Ciocalteu reagent, then $8 \mathrm{~mL}$ of $75 \mathrm{~g} \mathrm{~L}^{-1} \mathrm{Na}_{2} \mathrm{CO}_{3}$ was added. The tube was vortexed and allowed to stand for $5 \mathrm{~min}$ at $50{ }^{\circ} \mathrm{C}$. The absorbance was then measured at $760 \mathrm{~nm}$ by means of a Perkin Elmer Lambda 3 spectrophotometer (Waltham, Massachusetts, USA). The phenol content was estimated from a standard curve and expressed as gallic acid equivalents (GAE) $100 \mathrm{~g}^{-1}$ dry weight (DW).

\subsection{Statistical analysis}

The results obtained in one year of investigation (2007) were expressed as means \pm standard deviations (SD). Analysis of variance was performed on the data collected at the beginning of the kernel expansion stage $(\mathrm{DOY}=186)$, mid-late kernel expansion stage $(\mathrm{DOY}=214)$ and the end of the maturation stage $(\mathrm{DOY}=249)$ considering the cultivar, stage and their interactions as factors of variation. The least significant difference (LSD at $P=0.05$ ) for the comparison of the means was then calculated. Principal component analysis (PCA) was applied to the auto-scaled data matrix constituting the values of the nut chemical components of the kernel and pellicle analyzed in the three stages of development. All data processing was carried out using the SYSTAT software [34].

\section{Results and discussion}

\subsection{Dry matter content in the kernel and pellicle}

The increase in the kernel and pellicle dry matter content during nut growth is reported in figure 1. At the beginning of 


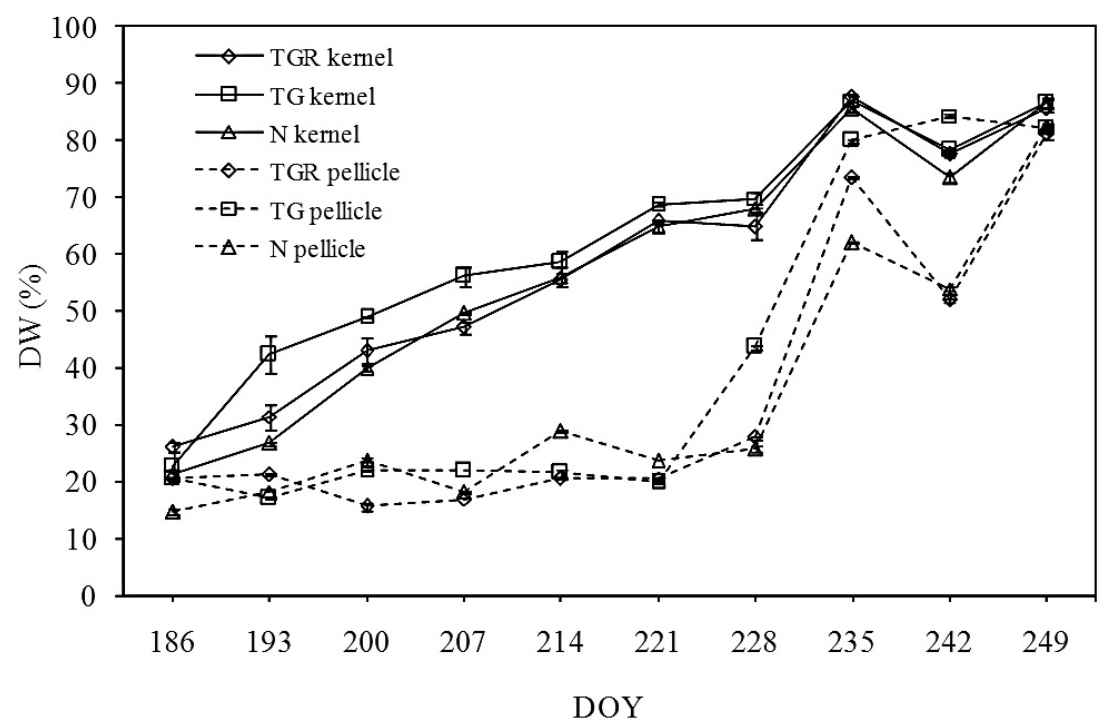

Figure 1. Dry matter content in the kernel and pellicle (\% DW) of 'Tonda Gentile Romana' (TGR), 'Tonda di Giffoni' (TG) and 'Nocchione' (N) hazelnut cultivars during the development of nuts (DOY = day of the year). Values are means of three replicates \pm standard deviations.

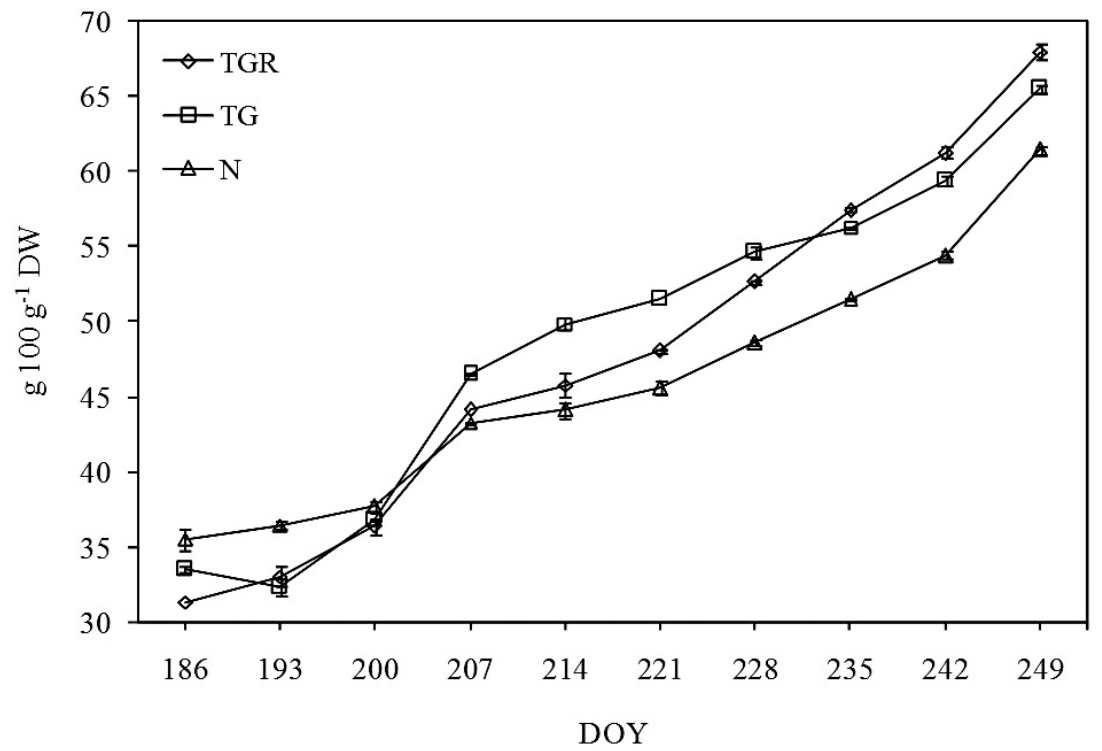

Figure 2. Total oil content in the kernel (in g $100 \mathrm{~g}^{-1} \mathrm{DW}$ ) of 'Tonda Gentile Romana' (TGR), 'Tonda di Giffoni' (TG) and 'Nocchione' (N) hazelnut cultivars during the development of nuts (DOY $=$ day of the year). Values are means of three replicates \pm standard deviations.

July, the dry matter content of the kernel was $26 \%$ in 'Tonda Gentile Romana', $22 \%$ in 'Tonda di Giffoni' and $21 \%$ in 'Nocchione'. 'Tonda di Giffoni' showed an earlier accumulation of dry matter in the kernel and a strong reduction of water content during July in comparison with the other cultivars.

The maximum dry matter content was observed at DOY = 235 and DOY $=249$, when all the cultivars showed about $85 \%$ DW, while at the end of August (DOY = 242) the moisture in the kernel was slightly higher, likely due to some rainfall events that occurred (22.4 mm) during the last week of August. The measurements confirm that the nuts accumulate dry matter until they drop to the ground, as also observed by Farinelli et al. [35] in 'Tonda di Giffoni' and 'Tonda Gentile Romana'.
The dry matter content in the pellicle varied during nut growth depending on the stage of development and the cultivar. All cultivars maintained low values (15-25\% DW) until the first week of August (DOY = 221), when a clear increase started. The dehydration of the pellicle started earlier in 'Tonda di Giffoni' and then increased in all cultivars in the second half of August, reaching final values at harvest $(\mathrm{DOY}=249)$ of about $82 \%$ DW for the three cultivars.

\subsection{Total oil content and fatty acid composition}

Oil accumulation in the kernel showed a slightly different trend in the three cultivars (figure 2) and was also significantly affected by the stage of nut development (table I). 
Table I. Total oil content (g $100 \mathrm{~g}^{-1} \mathrm{DW}$ ), main fatty acids ( $\%$ of total oil), total unsaturated fatty acids (PUFA) and the unsaturated/saturated acid ratio (U/S) in the kernel of hazelnut fruit expressed as the mean of cultivars, DOY $\left(186=5^{\text {th }}\right.$ July; $214=2^{\text {sd }}$ August; $249=6^{\text {th }}$ September $)$ and their interactions. (DOY = day of the year; C 16:0 = palmitic; C 18:0 = stearic; C 20:0 = arachic; C 18:1 = oleic; C 18:2 = linoleic; C 18:3 = linolenic; $\mathrm{C}$ 20:0 = arachic; TGR = 'Tonda Gentile Romana'; TG = 'Tonda di Giffoni'; N = 'Nocchione'; LSD = least significant difference; n.s. = not significant; n.d. $=$ not detected).

\begin{tabular}{|c|c|c|c|c|c|c|c|c|c|}
\hline & Oil & C 16:0 & C 18:0 & C 20:0 & C 18:1 & C $18: 2$ & C $18: 3$ & PUFA & $\mathrm{U} / \mathrm{S}$ \\
\hline \multicolumn{10}{|l|}{ Cultivar } \\
\hline TGR & 48.39 & 7.06 & 2.55 & 0.081 & 79.78 & 10.52 & 0.137 & 10.58 & 10.31 \\
\hline TG & 49.65 & 6.34 & 3.32 & 0.101 & 80.85 & 9.96 & 0.101 & 9.09 & 8.99 \\
\hline $\mathrm{N}$ & 47.06 & 5.29 & 2.22 & 0.120 & 83.66 & 7.48 & 0.093 & 7.58 & 11.95 \\
\hline $\operatorname{LSD}(P=0.05)$ & 1.79 & 0.74 & n.s. & n.s. & 1.60 & 2.29 & 0.001 & 2.26 & n.s. \\
\hline \multicolumn{10}{|l|}{ DOY } \\
\hline 186 & 33.50 & 5.72 & 2.59 & 0.132 & 81.54 & 9.07 & 0.080 & 9.15 & 10.75 \\
\hline 214 & 46.62 & 6.20 & 2.79 & 0.144 & 81.18 & 8.31 & 0.086 & 8.39 & 10.02 \\
\hline 249 & 64.98 & 6.77 & 2.23 & 0.057 & 81.57 & 10.58 & 0.105 & 9.69 & 10.48 \\
\hline $\operatorname{LSD}(P=0.05)$ & 1.94 & n.s. & 0.98 & 0.038 & n.s. & n.s. & 0.039 & n.s. & 1.39 \\
\hline \multicolumn{10}{|l|}{ DOY * Cultivar } \\
\hline \multirow{3}{*}{186} & 31.38 & 7.98 & n.d. & n.d. & 77.85 & 14.06 & n.d. & 14.06 & 11.51 \\
\hline & 33.55 & 7.04 & n.d. & n.d. & 81.55 & 11.40 & n.d. & 8.63 & 7.99 \\
\hline & 35.57 & 5.29 & 2.23 & 0.115 & 85.32 & 6.29 & 0.105 & 6.40 & 6.77 \\
\hline \multirow{3}{*}{214} & 45.82 & 7.11 & 2.57 & 0.150 & 80.91 & 8.16 & 0.093 & 8.25 & 9.09 \\
\hline & 49.87 & 6.24 & 3.65 & 0.161 & 80.42 & 8.76 & 0.078 & 8.84 & 8.85 \\
\hline & 44.17 & 5.25 & 2.16 & 0.120 & 82.21 & 8.01 & 0.086 & 8.10 & 9.10 \\
\hline \multirow{4}{*}{$\begin{array}{cc} & \text { TGR } \\
249 & \text { TG } \\
& \mathrm{N} \\
\text { LSD }(P=0.05)\end{array}$} & 67.96 & 6.09 & 2.53 & 0.124 & 80.57 & 9.35 & 0.070 & 9.42 & 10.32 \\
\hline & 65.54 & 5.74 & 2.99 & 0.144 & 80.58 & 9.72 & 0.084 & 9.80 & 10.15 \\
\hline & 61.45 & 5.34 & 2.27 & 0.126 & 83.47 & 8.15 & 0.088 & 8.24 & 11.78 \\
\hline & 3.11 & n.s. & n.s. & n.s. & n.s. & n.s. & n.s. & n.s. & n.s. \\
\hline
\end{tabular}

At the beginning of kernel expansion (DOY $=186$ ), 'Nocchione' showed a higher lipid content with respect to the other

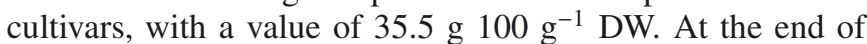
maturation $(\mathrm{DOY}=214)$, the highest oil content was in the nuts of 'Tonda Gentile Romana', which also showed a more uniform increase, as shown in figure 2.

At harvest time, the lipid contents were $61.4{\mathrm{~g} 100 \mathrm{~g}^{-1}}^{-1}$

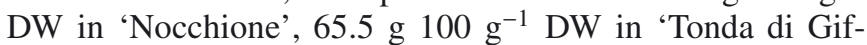

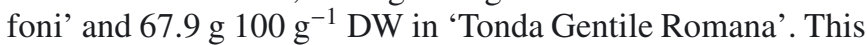
last value slightly exceeded the threshold for good nut storability [36]. The regular process of oil accumulation lessened in all the cultivars, on average, at the mid-late kernel expansion stages (DOY $=207-221)$. This can be explained by the qualitative modifications of lipid composition occurring during kernel growth and ripening [17], and the climate influence, mainly due to the high temperature (average of the minimum, maximum and mean temperature: 15,30 and $22^{\circ} \mathrm{C}$, respectively) and the low rainwater availability $(23 \mathrm{~mm})$ that occurred in late July-early August.

Palmitic, stearic, oleic and linoleic acids were the major fatty acids in the oil extracted from the kernel for all cultivars (table I), with oleic acid (18:1) accounting for $80-83 \%$ at harvest and stearic (18:0) and palmitic (16:0) saturated fatty acids accounting for less than $10 \%$ in all cultivars. The three cultivars differed slightly in their lipid composition. 'Nocchione' was characterized by a higher content of oleic acid $(83.4 \%)$ and lower content of stearic acid $(2.3 \%)$ at harvest time, whereas 'Tonda Gentile Romana' and 'Tonda di Giffoni' contained $80.5 \%$ of oleic acid (table I). These percentages are similar to those observed for some Spanish and U.S. commercial cultivars in previous research $[14,15]$. These results highlight the nutritional value of the cultivars tested and confirm the potential health benefits of hazelnut consumption, mainly related to the lowering of low-density lipoprotein cholesterol and total cholesterol and the consequent reduction of cardiovascular disease risks, due to the high content of MUFA (monounsaturated fatty acids) in its oil [37].

On average, oleic acid (18:1) increased slightly between the second half of July and the first week of August (DOY = 200-221), whereas linolenic acid (18:3) slightly decreased. The unsaturated/saturated ratio showed a constant increase during the nut development for all cultivars, with the only exception for the early stage $(\mathrm{DOY}=186)$, where the values were $11.5,8.0$ and 6.7 for TGR, TG and N, respectively. The fatty acid profile was significantly dependent on the stage of growth. Palmitic (16:0), linoleic (18:2) and linolenic (18:3) acids showed an increasing trend with respect to the stage of growth, whereas stearic (18:0) and arachic (20:0) saturated fatty acids decreased (table I).

\subsection{Starch, soluble sugars and organic acids in the kernel}

The contents of starch, soluble sugars and organic acids in the kernel showed significant differences among the cultivars, growing stage and their interaction (tables II and III). The starch accumulated in the kernel decreased in the first part of the nut development from values of 14.2, 19.0 and $20.2 \mathrm{~g}$ $100 \mathrm{~g}^{-1} \mathrm{DW}$ at the first stage $(\mathrm{DOY}=186)$ to $8.2,9.1$

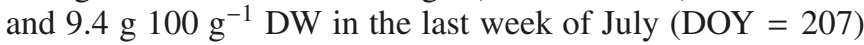




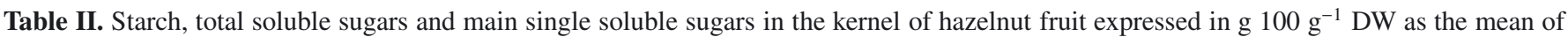
cultivars, DOY $\left(186=5^{\text {th }}\right.$ July; $214=2^{\text {sd }}$ August; $249=6^{\text {th }}$ September) and their interactions (DOY $=$ day of the year; TGR $=$ 'Tonda Gentile Romana'; TG = 'Tonda di Giffoni'; $\mathrm{N}$ = 'Nocchione'; LSD = least significant difference; n.s. = not significant).

\begin{tabular}{|c|c|c|c|c|c|c|c|}
\hline \multicolumn{2}{|c|}{ ( } & Starch & Soluble sugars & Sucrose & Glucose & Fructose & Stachyose \\
\hline \multicolumn{8}{|c|}{ Cultivar } \\
\hline \multicolumn{2}{|l|}{ TGR } & 10.05 & 5.49 & 3.72 & 0.30 & 0.78 & 0.40 \\
\hline \multicolumn{2}{|l|}{ TG } & 12.39 & 5.01 & 3.82 & 0.29 & 0.28 & 0.27 \\
\hline \multicolumn{2}{|l|}{$\mathrm{N}$} & 11.15 & 5.52 & 4.26 & 0.33 & 0.31 & 0.29 \\
\hline \multicolumn{2}{|c|}{$\operatorname{LSD}(P=0.05)$} & 2.09 & n.s. & 0.25 & 0.03 & n.s. & 0.10 \\
\hline \multicolumn{8}{|c|}{ DOY } \\
\hline \multicolumn{2}{|l|}{186} & 17.80 & 6.46 & 4.67 & 0.41 & 0.93 & 0.13 \\
\hline \multicolumn{2}{|l|}{214} & 14.30 & 4.30 & 2.77 & 0.40 & 0.30 & 0.34 \\
\hline \multicolumn{2}{|l|}{249} & 1.51 & 5.25 & 4.36 & 0.12 & 0.13 & 0.48 \\
\hline \multicolumn{2}{|c|}{$\operatorname{LSD}(P=0.05)$} & 1.74 & 0.50 & 0.32 & 0.08 & n.s. & 0.08 \\
\hline \multicolumn{8}{|c|}{ DOY * Cultivar } \\
\hline \multirow{3}{*}{186} & TGR & 14.22 & 7.07 & 3.93 & 0.54 & 1.99 & 0.32 \\
\hline & TG & 18.98 & 5.63 & 4.54 & 0.33 & 0.40 & 0.04 \\
\hline & $\mathrm{N}$ & 20.17 & 6.68 & 5.52 & 0.37 & 0.42 & 0.04 \\
\hline \multirow{4}{*}{214} & TGR & 14.13 & 4.19 & 2.92 & 0.27 & 0.24 & 0.32 \\
\hline & TG & 16.14 & 4.06 & 2.59 & 0.39 & 0.28 & 0.33 \\
\hline & $\mathrm{N}$ & 12.36 & 4.66 & 2.81 & 0.53 & 0.39 & 0.38 \\
\hline & TGR & 1.81 & 5.21 & 4.31 & 0.10 & 0.12 & 0.57 \\
\hline \multirow[t]{2}{*}{249} & TG & 1.80 & 5.33 & 4.34 & 0.15 & 0.16 & 0.43 \\
\hline & $\mathrm{N}$ & 0.92 & 5.21 & 4.43 & 0.11 & 0.11 & 0.46 \\
\hline \multicolumn{2}{|c|}{$\operatorname{LSD}(P=0.05)$} & 4.32 & 1.67 & 0.43 & 0.23 & n.s. & 0.18 \\
\hline
\end{tabular}

Table III. Total organic acids and main single organic acids in the kernel of hazelnut fruit expressed in $\mathrm{g} 100 \mathrm{~g}^{-1} \mathrm{DW}$ as the mean of cultivars, DOY $\left(186=5^{\text {th }}\right.$ July; $214=2^{\text {sd }}$ August; $249=6^{\text {th }}$ September) and their interactions (DOY = day of the year; TGR $=$ 'Tonda Gentile Romana'; TG = 'Tonda di Giffoni’; N = 'Nocchione'; LSD = least significant difference; n.s. = not significant).

\begin{tabular}{|c|c|c|c|c|c|}
\hline \multicolumn{2}{|c|}{ Cultivar } & Organic acids & Malic acid & Citric acid & Succinic acid \\
\hline \multicolumn{2}{|l|}{ TGR } & 0.93 & 0.48 & 0.32 & 0.01 \\
\hline \multicolumn{2}{|l|}{ TG } & 1.19 & 0.64 & 0.50 & 0.01 \\
\hline \multicolumn{2}{|l|}{$\mathrm{N}$} & 1.16 & 0.59 & 0.53 & 0.01 \\
\hline \multicolumn{2}{|c|}{$\operatorname{LSD}(P=0.05)$} & 0.18 & 0.03 & 0.03 & 0.003 \\
\hline \multicolumn{6}{|c|}{ DOY } \\
\hline \multicolumn{2}{|l|}{186} & 2.51 & 1.16 & 1.17 & 0.020 \\
\hline \multicolumn{2}{|l|}{214} & 0.38 & 0.23 & 0.12 & 0.008 \\
\hline \multicolumn{2}{|l|}{249} & 0.39 & 0.32 & 005 & 0.004 \\
\hline \multicolumn{2}{|c|}{$\operatorname{LSD}(P=0.05)$} & 0.19 & 0.11 & 0.11 & 0.002 \\
\hline \multicolumn{6}{|c|}{ DOY $*$ Cultivar } \\
\hline \multirow{3}{*}{186} & TGR & 1.98 & 0.83 & 0.87 & 0.030 \\
\hline & TG & 2.83 & 1.37 & 1.34 & 0.020 \\
\hline & $\mathrm{N}$ & 2.73 & 1.29 & 1.35 & 0.030 \\
\hline \multirow{3}{*}{214} & TGR & 0.34 & 0.24 & 0.08 & 0.008 \\
\hline & TG & 0.35 & 0.22 & 0.11 & 0.009 \\
\hline & $\mathrm{N}$ & 0.45 & 0.24 & 0.18 & 0.007 \\
\hline \multirow{3}{*}{249} & TGR & 0.46 & 0.38 & 0.05 & 0.004 \\
\hline & TG & 0.40 & 0.33 & 0.06 & 0.004 \\
\hline & $\mathrm{N}$ & 0.32 & 0.26 & 0.04 & 0.005 \\
\hline \multicolumn{2}{|c|}{$\operatorname{LSD}(P=0.05)$} & 0.31 & 0.06 & 0.06 & 0.005 \\
\hline
\end{tabular}

in TGR, TG and N, respectively (figure 3). At the beginning of August (DOY $=214$ ) the starch accumulation showed a steep increase in all cultivars, followed by a steady decrease to values lower than 1-2 g $100 \mathrm{~g}^{-1} \mathrm{DW}$ at harvest time. On average, starch content in the kernel was significantly high at the first

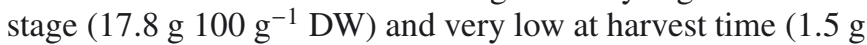
$100 \mathrm{~g}^{-1} \mathrm{DW}$ ) (table II).
Synthesis and accumulation of soluble sugars was high in the first half of July (DOY $=193$ ), declined in the second decade of the month $(\mathrm{DOY}=200)$, and then resumed until harvest time, where all cultivars showed final values of

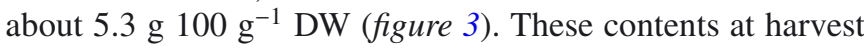
time are in agreement with those observed in other research on hazelnut $[3,16]$. 


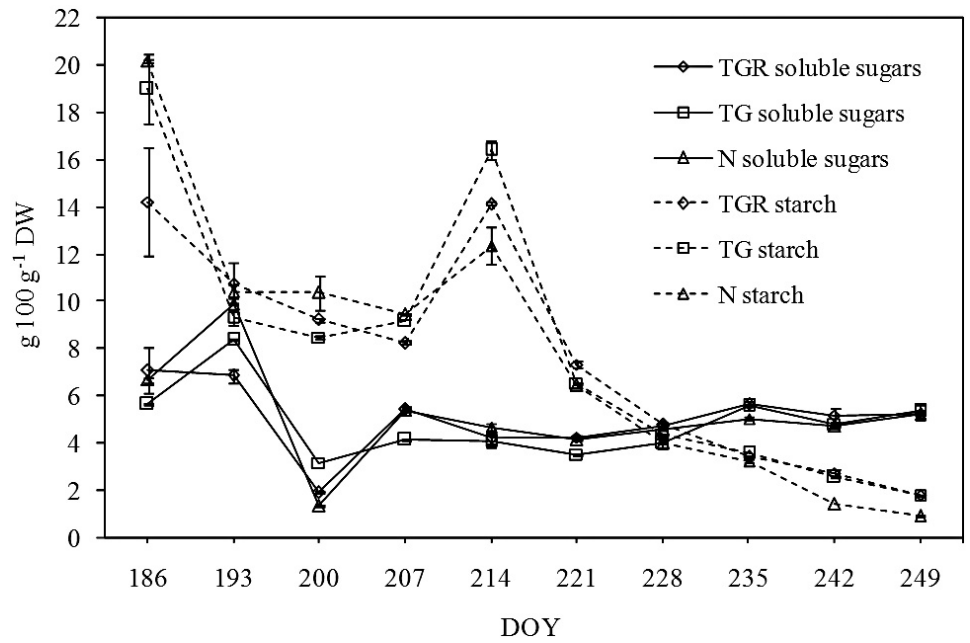

Figure 3. Total soluble sugars and starch content in the kernel (in $\mathrm{g} 100 \mathrm{~g}^{-1} \mathrm{DW}$ ) of 'Tonda Gentile Romana' (TGR), 'Tonda di Giffoni' (TG) and 'Nocchione' $(\mathrm{N})$ hazelnut cultivars during the development of nuts (DOY $=$ day of the year). Values are means of three replicates \pm standard deviations.

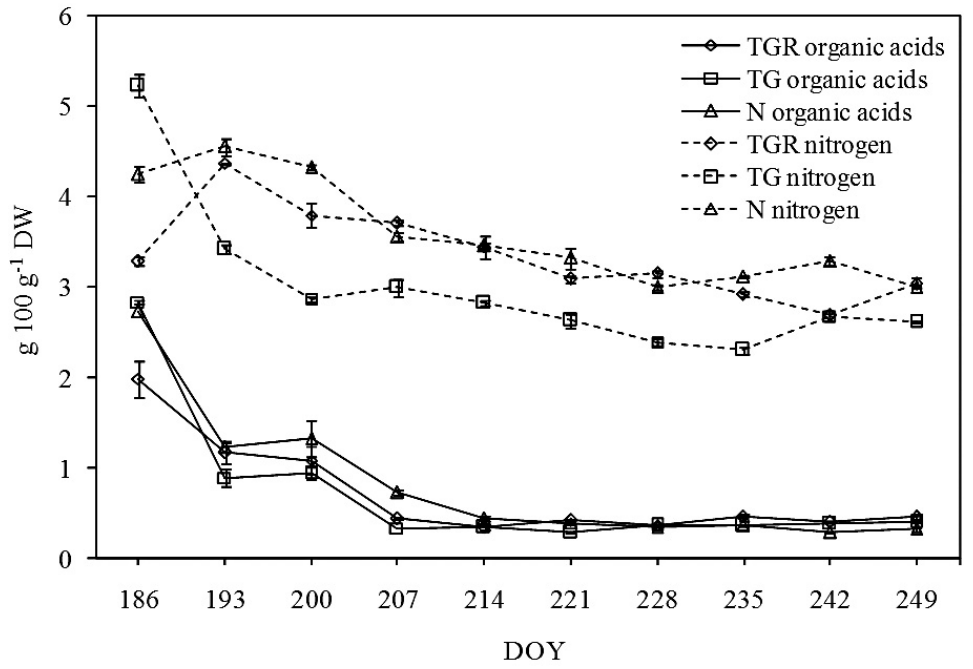

Figure 4. Total organic acids and nitrogen contents in the kernel (in g $100 \mathrm{~g}^{-1} \mathrm{DW}$ ) of 'Tonda Gentile Romana' (TGR), 'Tonda di Giffoni' (TG) and 'Nocchione' (N) hazelnut cultivars during the development of nuts (DOY $=$ day of the year). Values are means of three replicates \pm standard deviations.

The decrease in the sugar level $($ DOY $=200)$ can be related to the intensification of oil accumulation in the kernel (figure 2), which is supported by the carbohydrates available in situ as the main source of energy and substrate. We may suppose that starch decrease $($ DOY $=207$ and after DOY $=214)$ has the same origin. Studies on the temporal changes in gene expression during the processes of storage compound accumulation in the seeds of the model species Arabidopsis described a transient accumulation of starch, and attributed its later disappearance to it being used as a carbon source for fatty acid and protein synthesis [38].

Sucrose was the main sugar in the kernel, representing more than $80 \%$ of total soluble sugars at harvest time for all the cultivars, followed by stachyose, fructose and glucose. Sucrose also showed a similar trend to that of total sugars, whereas stachyose was characterized by a very low content until the end of July (DOY $=207)$ and by an increase in August with values

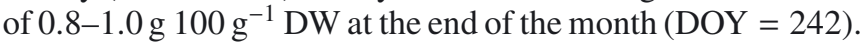

Fructose and glucose, representing respectively about $1.8-3.2 \%$ and $1.8-2.8 \%$ of the total sugars at harvest time, showed a more uniform trend during the nut development without the high fluctuations observed for sucrose.

Considering the early, middle and final stages, total soluble sugars and each carbohydrate were significantly affected by the cultivar, sampling date and their interaction, with the exception of fructose, for which a high variability among the replicates was observed (table II).

The content of organic acids in the kernel, represented by malic ( $82 \%$ of the total), citric (13-15\%) and succinic acids (1-2\%), was quite high at the beginning of July (DOY 186), showing values of 2.0,2.8 and $2.7 \mathrm{~g} 100 \mathrm{~g}^{-1} \mathrm{DW}$ in TGR, TG

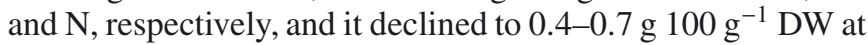
the end of the month (DOY $=207)$, remaining almost constant until harvest time (figure 4) (data not reported).

Similarly to sugars, the organic acids were significantly affected by the sampling date and their interaction, as shown in 
Table IV. Nitrogen in the kernel and total phenol content in the kernel and pellicle of hazelnut fruit expressed as the mean of cultivars, DOY $\left(186=5^{\text {th }}\right.$ July; $214=2^{\text {sd }}$ August; $249=6^{\text {th }}$ September $)$ and their interactions (DOY $=$ day of the year; TGR $=$ Tonda Gentile Romana; TG $=$ Tonda di Giffoni; $\mathrm{N}=$ Nocchione; LSD = least significant difference; n.s. = not significant).

\begin{tabular}{|c|c|c|c|c|}
\hline & & \multirow{2}{*}{$\begin{array}{c}\text { Nitrogen } \\
\left(\mathrm{g} 100 \mathrm{~g}^{-1} \mathrm{DW}\right)\end{array}$} & \multicolumn{2}{|c|}{ Total phenol content } \\
\hline & & & $\begin{array}{c}\text { Kernel } \\
\left(\mathrm{mg} \mathrm{GAE} 100 \mathrm{~g}^{-1} \mathrm{DW}\right)\end{array}$ & $\begin{array}{c}\text { Pellicle } \\
\left(\mathrm{g} \text { GAE } 100 \mathrm{~g}^{-1} \mathrm{DW}\right)\end{array}$ \\
\hline \multicolumn{5}{|c|}{ Cultivar } \\
\hline TGR & & 3.50 & 28.99 & 6.87 \\
\hline TG & & 3.55 & 29.15 & 5.24 \\
\hline $\mathrm{N}$ & & 3.56 & 30.59 & 4.34 \\
\hline LSD & $0.05)$ & n.s. & $n . s$ & 0.21 \\
\hline \multicolumn{5}{|c|}{ DOY } \\
\hline 186 & & 4.25 & 20.25 & 3.80 \\
\hline 214 & & 3.24 & 21.50 & 8.76 \\
\hline 249 & & 2.88 & 46.99 & 3.89 \\
\hline LSD & $0.05)$ & 0.39 & 2.47 & 1.32 \\
\hline \multicolumn{5}{|c|}{ DOY * Cultivar } \\
\hline \multirow{3}{*}{186} & TGR & 3.28 & 21.98 & 3.70 \\
\hline & $\mathrm{TG}$ & 5.22 & 17.60 & 3.13 \\
\hline & $\mathrm{N}$ & 4.25 & 21.16 & 4.58 \\
\hline \multirow{3}{*}{214} & TGR & 3.44 & 17.44 & 12.14 \\
\hline & TG & 2.82 & 25.50 & 8.88 \\
\hline & $\mathrm{N}$ & 3.45 & 21.58 & 5.26 \\
\hline \multirow{3}{*}{249} & TGR & 3.04 & 47.56 & 4.77 \\
\hline & TG & 2.61 & 44.36 & 3.72 \\
\hline & $\mathrm{N}$ & 2.99 & 49.05 & 3.18 \\
\hline LSD & $0.05)$ & 0.32 & 6.39 & 0.37 \\
\hline
\end{tabular}

table III. The total content was significantly higher at the beginning of nut filling, when TGR showed lower values than TG and N, and declined in the subsequent steps, without differences among cultivars (table III). Since high acidity generally reduces the perception of sweetness [39], the lower content of organic acids could be one of the reasons for the better appreciation of immature nuts collected at the end of July with respect to the beginning of July [27].

\subsection{Nitrogen content in the kernel}

The nitrogen content in the kernel showed a constant slight decrease from early July (DOY = 193) until the end of August (DOY $=242)$, with some differences among the cultivars as shown in figure 4. During the nut development, 'Tonda di Giffoni' showed the lowest content of nitrogen compared with the other cultivars for almost all sampling data, with the exception of the early stage (DOY $=186)$, when the nitrogen con-

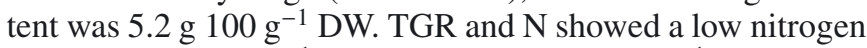

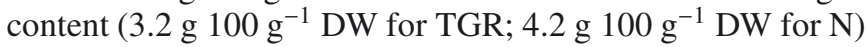
at the beginning of the kernel expansion stage $(\mathrm{DOY}=186)$

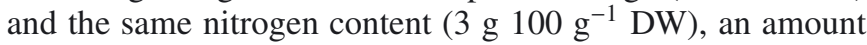
slightly higher than TG, at harvest time. Considering the early $(\mathrm{DOY}=186)$, middle $(\mathrm{DOY}=214)$ and final $(\mathrm{DOY}=214)$ stages, the nitrogen content in the kernel was significantly affected by the sampling date, as shown in table $I V$.

The knowledge of the accumulation of nitrogen in the kernel during nut growth can be useful to manage the nitrogen fertilization in the hazelnut orchards more rationally. The high accumulation of proteins during the kernel filling indicates that this growth phase has a high requirement for suitable nitrogen availability [22].

\subsection{Total phenol content in the kernel and pellicle}

Phenolics in hazelnut kernels protect the seed from oxidation during storage and influence the taste by giving a slight astringency and bitterness appreciated in fresh nuts. This same taste is not desirable in roasted nuts and is most noticeable in cultivars that do not release the pellicle during roasting [2]. In recent years, the antioxidant activity of phenolic compounds and the potential positive effect of nut consumption on human health have been evidenced $[8,33]$. Among nut species, hazelnuts have an intermediate content of total polyphenols, between the high levels of walnuts, pecans and pistachios and the low levels of pine and macadamia nuts, and have been defined as a good source of phenolics with high antioxidant potential [23].

The total phenol content in the kernel and pellicle varied as a consequence of the cultivar, stage of development and their interaction (table IV), showing a fluctuating trend during the nut development (figures 5 and 6). At harvest time, the total phenol content in the kernel was similar to that observed in the recent literature on other cultivars [23]. On average, the total phenol content in the kernel, expressed as the mean of the cultivars, was more than double at harvest time (47 mg GAE $100 \mathrm{~g}^{-1} \mathrm{DW}$ ) compared with the values observed at the beginning of the kernel expansion stage (20.2 mg GAE $100 \mathrm{~g}^{-1} \mathrm{DW}$ ) and mid-late kernel expansion stage (21.5 mg GAE $\left.100 \mathrm{~g}^{-1} \mathrm{DW}\right)$, as reported in table IV. 


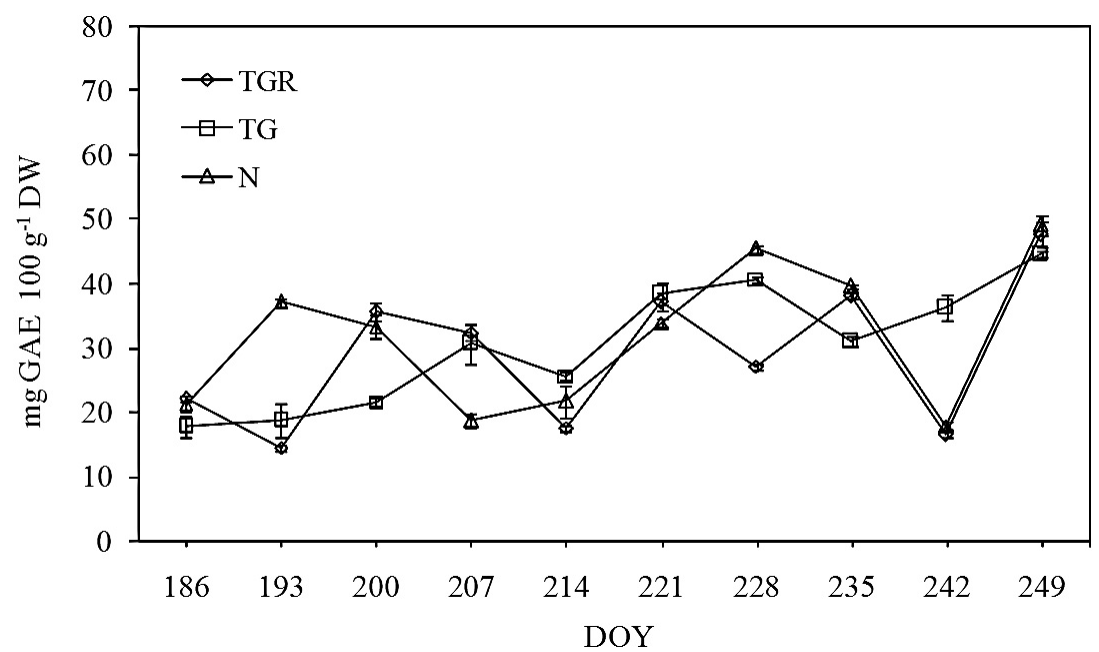

Figure 5. Total phenol content in the kernel (in mg GAE $100 \mathrm{~g}^{-1} \mathrm{DW}$ ) of 'Tonda Gentile Romana' (TGR), 'Tonda di Giffoni' (TG) and 'Nocchione' (N) hazelnut cultivars during the development of nuts (DOY = day of the year). Values are means of three replicates \pm standard deviations.

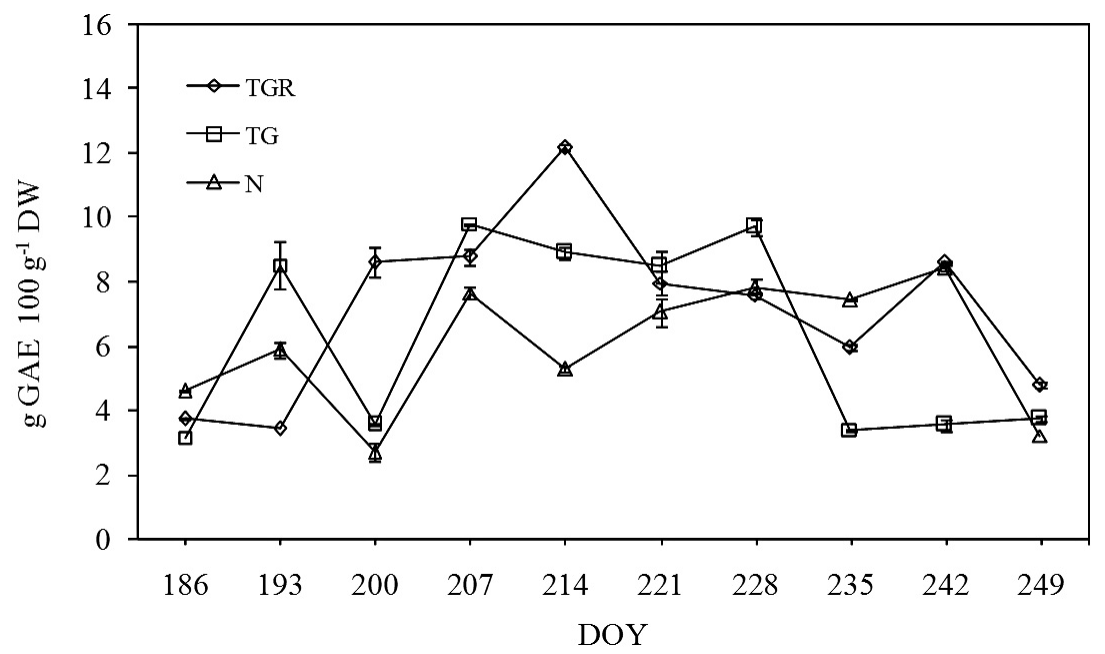

Figure 6. Total phenol content in the pellicle (in g GAE $100 \mathrm{~g}^{-1} \mathrm{DW}$ ) of 'Tonda Gentile Romana' (TGR), 'Tonda di Giffoni' (TG) and 'Nocchione' $(\mathrm{N})$ hazelnut cultivars during the development of nuts (DOY $=$ day of the year). Values are means of three replicates \pm standard deviations.

The total phenol content in the pellicle was much higher than that observed in the kernel, and it also showed a different trend to that observed in the kernel (figure 6). On average, the highest concentrations of phenolics were revealed during the period between late July (DOY $=207)$ and early August $($ DOY $=228)$. The highest amount of phenolic compounds in the pellicle occurred at the mid-late kernel expansion stage for TGR (12.1 g GAE $100 \mathrm{~g}^{-1} \mathrm{DW}$ ), which also showed a higher content than the other cultivars, characterized at the same stage by values of 8.8 and $5.2 \mathrm{~g} \mathrm{GAE} 100 \mathrm{~g}^{-1}$ DW in $\mathrm{TG}$ and $\mathrm{N}$, respectively. At harvest time, the cultivars showed slight differences and TGR still had the highest amount of total phenols (4.7 g GAE $100 \mathrm{~g}^{-1}$ DW) compared with TG (3.7 g GAE $100 \mathrm{~g}^{-1}$ DW) and $\mathrm{N}\left(3.2 \mathrm{~g} \mathrm{GAE} 100 \mathrm{~g}^{-1} \mathrm{DW}\right)$.

The significant interaction of cultivar $\mathrm{x}$ DOY indicates that the highest total phenol content was accumulated in the pellicle in the middle stage (DOY 214) of seed filling in all cultivars, with a greater increase in TGR than in the other cultivars $(t a-$ ble IV).

The nut and kernel traits, determined according to Manzo et al. [40] and Köksal et al. [41], showed that at the beginning of July the nuts had almost reached the final size $(20.4 \mathrm{~mm}$ as the mean of the cultivars) and very few differences were observed in the subsequent stages of collection, whereas the kernel weight was about $70 \%$ of the final weight, which ranged from $1.2 \mathrm{~g}$ in 'Nocchione' and $1.3 \mathrm{~g}$ in 'Tonda di Giffoni' and 'Tonda Gentile Romana'. External signs of the ripening process were observed on the shells, that were already partially hardened and a light green color at the beginning of July, and showed a gradual color change from green to light brown starting from the second week of August $(\mathrm{DOY}=221)$ without relevant differences among the cultivars.

The consumption of "green hazelnuts" could be an interesting 'old novelty' for an expansion of the range of hazelnut 
Table V. Loadings of the original variables to the first three principal components (in bold: highest loading values).

\begin{tabular}{lccc}
\hline Variable & PC1 & PC2 & PC3 \\
\hline Oil content & $\mathbf{- 0 . 8 8 3}$ & -0.156 & 0.388 \\
C 16:0 & 0.542 & -0.600 & -0.360 \\
C 18:0 & $-\mathbf{0 . 8 5 8}$ & 0.311 & -0.176 \\
C 20:0 & $-\mathbf{0 . 8 7 7}$ & 0.344 & -0.214 \\
C 18:1 & -0.090 & $\mathbf{0 . 8 8 9}$ & 0.326 \\
C 18:2 & 0.524 & $\mathbf{- 0 . 8 2 0}$ & 0.025 \\
C 18:3 & $-\mathbf{0 . 7 4 6}$ & 0.549 & -0.030 \\
PUFA & 0.301 & $\mathbf{- 0 . 9 3 2}$ & -0.019 \\
U/S & -0.324 & $\mathbf{- 0 . 8 3 1}$ & 0.279 \\
Starch & $\mathbf{0 . 7 1 3}$ & 0.409 & -0.551 \\
Soluble sugars & $\mathbf{0 . 7 2 6}$ & -0.129 & 0.521 \\
Sucrose & 0.371 & 0.289 & $\mathbf{0 . 8 4 2}$ \\
Fructose & 0.597 & -0.047 & -0.580 \\
Glucose & 0.679 & -0.587 & -0.134 \\
Stachyose & $-\mathbf{0 . 7 7 6}$ & -0.563 & 0.129 \\
Organic acids & $\mathbf{0 . 9 3 2}$ & 0.270 & 0.209 \\
Malic acid & $\mathbf{0 . 8 8 5}$ & 0.322 & 0.284 \\
Citric acid & $\mathbf{0 . 9 2 7}$ & 0.323 & 0.163 \\
Succinic acid & $\mathbf{0 . 9 1 3}$ & 0.101 & 0.016 \\
Nitrogen & $\mathbf{0 . 7 4 7}$ & 0.429 & 0.134 \\
Phenols in kernel & -0.647 & -0.266 & $\mathbf{0 . 7 0 1}$ \\
Phenols in pellicle & -0.330 & 0.148 & $-\mathbf{0 . 8 2 3}$ \\
\hline & & &
\end{tabular}

products offered in niche markets. The main information needed to support the utilization of "green hazelnuts" for this re-proposal is the identification of the most appropriate stage of harvest in order to obtain valuable sensory characteristics and a sufficient shelf life. In recent research [27], nuts of 'Tonda Gentile Romana' collected at three different times before the end of maturation were submitted to a panel of trained judges; the results of the sensory analysis indicated that late July-early August was the time of harvest when the best seed taste and firmness and ease of shell removal occurred. In our trial, this time corresponds to the phase between DOY $=207$ and 214, when the moisture content in the kernels of 'Tonda Gentile Romana' and 'Nocchione' was about 60\%, the pellicle was well hydrated and the content of sugars, lipids and protein had reached a good level. The decrease in organic acids may also have contributed to a better taste and the reduced astringency perceived in the cited taste panel [27].

\subsection{Principal component analysis (PCA)}

The analytical data set of the chemical constituents of the kernel and pellicle in the three cultivars and stages of nut development was evaluated by principal component analysis (PCA) in order to synthesize the information and examine the variability of case distribution and its determinants. The first three principal components (PCs), which were selected on the basis of the Kaiser criterion with eigenvalues higher than one [42], explained $89.1 \%$ of the total variance.

The PC1 (48.3\% of the total variance) represents a factor negatively related to the content of oil and stearic, arachic and linolenic acids, and positively related to starch and soluble sugars, nitrogen and organic acids (table $V$ ). This factor corresponds to an opposite contribution of lipids, mainly the saturated ones, with respect to carbohydrates, and protein represents an indicator of the seed maturity, with high values corresponding to the initial stages of seed formation (low lipids, high starch, sugar reserves and energy sources, high proteins) and low values to the mature state (high lipids, with a presence of low saturated and polyunsaturated fatty acids).

The variables that mostly weighed on PC2 $(24.7 \%$ of the total variance) were oleic acid with a positive sign and linoleic acid, PUFA and the unsaturated/saturated ratio with a negative sign. PC3 was related positively with sucrose and phenolic content in the kernel and negatively with phenolics in the pellicle.

The analysis of PC1 versus PC2 showed a separation between the samples according to the stage of kernel development and genotype (figure 7), with positive values at the beginning of nut development $(\mathrm{DOY}=186)$ and negative values in the medium stage $(\mathrm{DOY}=214)$ and at maturity $(\mathrm{DOY}=249)$. The differences among the three cultivars are mainly evident for PC2 and at the immature stage, when TGR shows negative values of PC2, which indicate a different profile of fatty acid, with a lower content of oleic acid and higher contents of polyunsaturated fatty acids, in comparison with TG and mostly N.

PC3 discriminated the second and final stage of seed growth, besides the initial stage. The values of PC3 in the positive left quadrant describe the mature nuts as sweeter and with a higher content of phenolics in the kernel and lower in the pellicle than in the second developmental stage. In all three stages $\mathrm{N}$ is well separated from the other cultivars by higher values of PC3, whereas TGR is distinguished by the negative PC3 in the first stage of growth.

\section{Conclusion}

The nut composition during seed growth is characterized by several important simultaneous processes: oil accumulation, variation of sugar content, decrease in acidity and nitrogen content, dehydration, and qualitative modifications of lipid, acid and sugar profiles. The consequence of these dynamics is a change in sensory, nutritional and health quality, resulting in different possibilities of use in different stages of seed development and for different purposes.

As regards the stage of nut growth and seed maturation, the consumption of immature nuts certainly may have only a marginal importance with respect to the use of mature nuts by consumers and industry, but it could be of interest as a way of product differentiation both in the areas of hazelnut cultivation and in the latitudes where the nut maturation cannot be fully attained. On the basis of the comparison of the results obtained in this study and in previous research [27] the best time for harvest aimed at this particular use can be identified at the end of July-early August, depending on the cultivar. At the green stage, the high moisture content in both the seed and pellicle and the high sugar concentration may be associated with the perception of kernel tenderness and delicate taste and justifies the new interest in this traditional 'minor' use of unripe nuts [27]. 

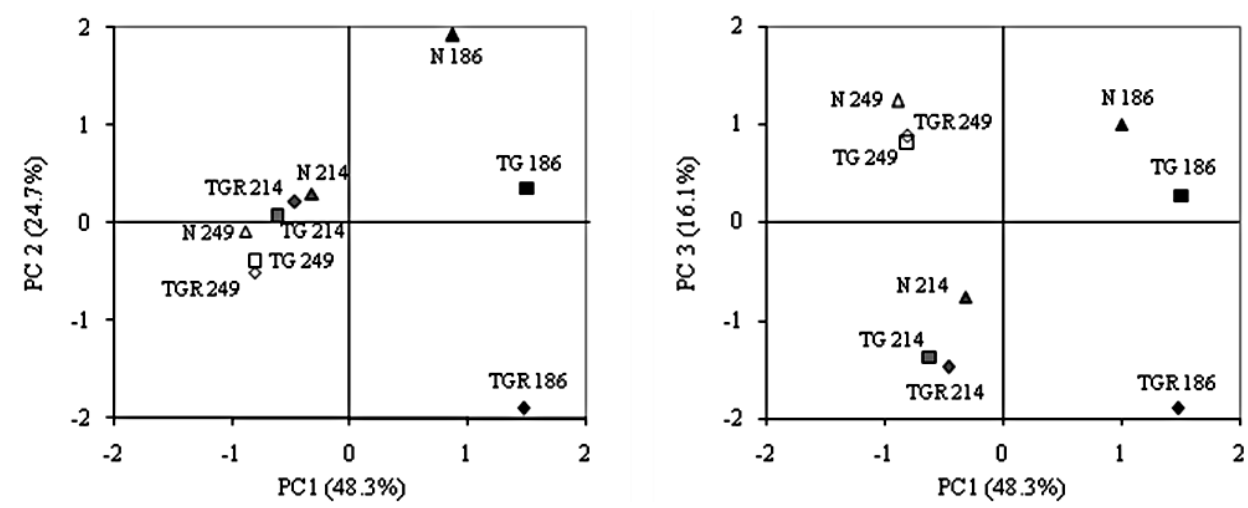

Figure 7. Plots of the score values on the first and second principal components (PC1 vs. PC2) (A) and on the first and third principal components (PC1 vs. PC3) (B) with the explained variance. [(TGR) 'Tonda Gentile Romana'; (TG) 'Tonda di Giffoni'; (N) 'Nocchione'; $\mathrm{DOY}=184,214,246(\mathrm{DOY}=$ day of the year) $]$.

The trend of oil accumulation and the decrease in moisture in the kernel and total phenolics in the pellicle stress the importance of a timely harvest of fully ripe nuts for industry or fresh consumption. However, in most countries the hazelnuts are mechanically harvested after they have fallen on the ground and are in a state of physiological maturity. The way to obtain nuts of high quality mainly relies then, on the adoption of the best association between genotype, environment and orchard management during plant and nut growth, in order to ensure the best completion of synthesis, accumulation and changes in nut chemical components. In this light, the timely harvest of fallen nuts becomes critical, as also stated by Farinelli et al. [35]. On the other hand, the harvest of nuts that are not fully mature may occur when nut abscission is stimulated by bioregulators [43], or by shaking the plant [44], or by handpicking, as sometimes still occurs in Turkish cultivars.

A key phase in the definition of the chemical composition of mature nuts spans from the second part of July to the first half of August, when the maximum oil accumulation in the kernel occurs. In this period, important physiological processes are going on, strictly dependent on environmental conditions and orchard management. The results indicate that the composition of the kernel and pellicle is cultivar-dependent during some stages of nut growth, with differences mainly related to the decrease in the water content. The pellicle of the cultivars tested revealed a high content of total polyphenols, secondary metabolites with antioxidant activities and closely related to nut stability during storage $[33,45]$ and to fresh and roasted nut taste [2]. The presence of phenols in the pellicle and their variation during nut growth, and the high level of monounsaturated fatty acids are interesting aspects deserving more attention for the promotion of nut consumption and for the evaluation of the hazelnut pellicle as a potential source of natural antioxidants as food additives [46]. The higher content of phenolics in the middle stages of nut growth and in the cultivars 'Tonda Gentile Romana' and 'Tonda di Giffoni' indicates that these cultivars harvested at this maturity stage are good sources of antioxidants for pharmaceutical uses.

Acknowledgements. The authors thank Dr. David C. Smith (Oregon State University, Corvallis, OR, USA) for reviewing the manuscript.

\section{References}

[1] FAO Statistical Yearbook 2008-20012, FAO, Rome. 2012.

[2] Mehlenbacher S.A., Hazelnuts (Corylus), Acta Hortic. 290 (1991) 791-836.

[3] Botta R., Gianotti C., Richardson D., Halzenut variety organic acids, sugars and total lipid fatty acids, Acta Hortic. 351 (1994) 693-699.

[4] Özdemir M., Açkurt F., Kaplan M., Yildiz M., Löker M., Gürkan T., Biringen G., Okay A., Seyhan F.G., Evaluation of new Turkish hybrid hazelnut (Corylus avellana L.) varieties: fatty acid composition, $\alpha$-tocopherol content, mineral composition and stability, Food Chem. 73 (2001) 411-415.

[5] Alasalvar C., Karamac M., Amarowizc R., Shahidi F., Antioxidant and radical activities in extracts of hazelnut kernel (Corylus avellana L.) and hazelnut leafy cover, J. Agric. Food Chem. 54 (2006) 4826-4832.

[6] Köksal A.Í., Artik N., Şimşek A., Güne N., Nutrient composition of hazelnut (Corylus avellana L.) varieties cultivated in Turkey, Food Chem. 99 (2006) 509-515.

[7] Richardson D.G., The health benefits of heating hazelnuts: implications for blood lipid profile, coronary heart disease and cancer risks, Acta Hortic. 445 (1997) 295-300.

[8] Salas-Salvadò J., Megias I., Health and tree nuts: scientific evidence of disease prevention, Acta Hortic. 686 (2005) 507-513.

[9] Parcerisa J., Codony R., Boatella J., Rafecas M., Triacylglycerol and Phospholipid composition of hazelnut (Corylus avellana L.) lipid fraction during fruit development, J. Agric. Food Chem. 47 (1999) 1410-1415.

[10] Amaral J.S., Cunha S.C., Santos A., Alves M.R., Seabra R.M., Oliveira B.P.P., Influence of cultivar and environment conditions on the triacylglycerol profile of hazelnut (Corylus avellana L.), J. Agric. Food Chem. 54 (2006) 449-456.

[11] Bignami C., Cristofori V., Troso D., Bertazza G., Kernel quality and composition of hazelnut (Corylus avellana L.) cultivars, Acta Hortic. 686 (2005) 477-484.

[12] Cristofori V., Ferramondo S., Bertazza G., Bignami C., Nut traits, kernel quality and composition and sensory evaluation of some hazelnut cultivars, Acta Hortic. 845 (2009) 657-664.

[13] Parcerisa J., Boatella J., Codony R., Farran A., Garcia J., Lopez A., Rafecas M., Romero A., Influence of variety and geographical origin on the lipid fraction of hazelnut (Corylus avellana L.) from Spain. I: fatty acid composition, Food Chem. 48 (1993) 411-414. 
[14] Parcerisa J., Boatella J., Codony R., Rafecas M., Castellote A.I., Garcia J., Lopez A., Romero A., Comparison of fatty acid and triacylglycerol composition of different hazelnut varieties (Corylus avellana L.) cultivated in Catalonia (Spain), J. Agric. Food Chem. 43 (1995) 13-16.

[15] Savage G.P., McNeil D.L., Dutta P.C., Lipid composition and oxidative stability of oils in hazelnuts (Corylus avellana L.) grown in New Zealand, J. Am. Oil Chem. Soc. 74 (1997) 755759.

[16] Cristofori V., Ferramondo S., Bertazza G., Bignami C., Nut and kernel traits and chemical composition of hazelnut (Corylus avellana L.) cultivars, J. Sci. Food Agric. 88 (2008) 1091-1098.

[17] Lotti G., Paradossi C., Marchini F., La biosintesi dei gliceridi nei semi di Corylus avellana L. durante la maturazione, La rivista della Società Italiana di Scienza dell'Alimentazione (4) (1985) 279-286.

[18] Ebrahem K.S., Richardson D.G., Tetley R.M., Changes in oil content, fatty acid and vitamin E composition in developing hazelnuts kernels, Acta Hortic. 351 (1994) 669-676.

[19] Koyuncu M.A., Bostan S.Z., Islam A., Change of fat content and fatty acid composition during the fruit development period in the hazelnuts Tombul and Palaz cultivars grown in Ordu, Acta Hortic. 445 (1997) 229-233.

[20] Alasalvar C., Seyhan F., Ozay G., Ertaž E., Satir G., Chemical changes of three native Turkish hazelnut varieties (Corylus avellana L.) during fruit development, Food Chem. 105 (2007) 590596.

[21] Seyhan F., Ozay G., Saklar S., Ertas E., Satır G., Alasalvar C., Chemical changes of three native Turkish hazelnut varieties (Corylus avellana L.) during fruit development, Food Chem. 105 (2007) 590-596.

[22] Wei L., Zhai Q., The dynamics and correlation between nitrogen, phosphorus, potassium and calcium in a hazelnut fruit during its development, Front. Agric. China (3) (2010) 352-357.

[23] Kornsteiner M., Wagner K.H., Elmadfa I., Tocopherols and total phenolics in 10 different nuts types, Food Chem. 98 (2006) 381387.

[24] Solar A., Veberiè R., Bacchetta L., Botta R., Drogoudi P., Metzidakis I., Rovira M., Sarraquigne J.P., Silva A.P., Phenolic characterization of some hazelnut cultivars from different European germplasm collections, Acta Hortic. 845 (2009) 613-618.

[25] Nanos G.D., Kazantzis I., Kefalas P., Petrakis C., Stavroulakis G.G., Irrigation and harvest time affect almond kernel quality and composition, Sci. Hortic. 96 (2002) 249-256.

[26] Carpentieri F., Il nocciuolo. F.lli Ottavi, Casale Monferrato, 1906.

[27] Moscetti R., Frangipane M.T., Monarca D., Cecchini M., Massantini R., Maintaining the quality of unripe, fresh hazelnuts through storage under modified atmospheres, Postharvest Biol. Technol. 65 (2012) 33-38.

[28] Thompson M.M., Growth and development of the pistillate flower and nut in "Barcelona" Filbert, J. Am. Soc. Hortic. Sci. 104 (1979) 427-432.
[29] Regione Lazio, Reg. CE n. 1257 (2000-2007). Rural Development Plan, Rome, 2000.

[30] B.O.E., (1995). R.D. 2257/1994 de 25-II-94. B.O.E. No. 52 del 02/03/1995, 52: 7167-7237.

[31] Bartolozzi F., Bertazza G., Bassi D., Cristoferi G., Simultaneous GLC determination of soluble sugars and organic acids as trimethylsilyl derivates in apricot fruits by gas-liquid chromatography, J. Chromatogr. 758 (1997) 99-107.

[32] Singleton V.L., Orthofer R., Lamuela-Raventos R.M., Analysis of total phenols and other oxidation substrates and antioxidants by means Folin-Ciocalteu reangent, Methods Enzymol. 299 (1999) 152-178.

[33] Yuritas H.C., Schafer H.W., Warthesen J.J., Antioxidant activity of nontocopherol hazelnut (Corylus spp.) phenolics, J. Food Sci. 2 (2000) 276-279.

[34] Wilkinson L., 1998. SYSTAT, Version 8.0. SPSS, Chicago, IL.

[35] Farinelli D., Tombesi A., Boco M., Trappoloni C.S., Hazelnut (Corylus avellana L.) kernel quality during maturity in central Italy, Acta Hortic. 556 (2001) 553-558.

[36] Garrone W., Vacchetti M., La qualità delle nocciole in rapporto alle esigenze dell'industria dolciaria utilizzatrice, Acta Hortic. 351 (1994) 641-656.

[37] Reaven P.D., Witztum J.L., Oxidised low density lipoproteins in atherogenesis: role of dietary modification, Ann. Rev. Nutr., 16 (1996) 51-71.

[38] Ruuska S.A., Girke T., Benning C., Ohlrogge B., Contrapuntal networks of gene expression during Arabidopsis seed filling, Plant Cell 14 (2002) 1191-1206.

[39] Lobit P., Genard M., Soing P. and Habib R., Modelling malic acid accumulation in fruits: relationships with organic acids, potassium, and temperature, J. Exp. Bot. 57 (2006) 1471-1483.

[40] Manzo P., Tamponi G., Monografia di cultivar di nocciuolo, Istituto Sperimentale di Frutticoltura, Rome, 1982.

[41] Köksal A.Y., Celik H., Inventory of hazelnut research, germplasm, and references, REU Tech Ser 56, FAO Regional Office for Europe, 2000.

[42] Kaiser H.F., The varimax criterion for analytic rotation in factor analysis, Psychometrika 23 (1958) 187-200.

[43] Limongelli F., Chiariotti A., Possibilità di impiego degli etilen promotori nella raccolta del nocciolo, Acta Hortic. 351 (1994) 473-480.

[44] Yildiz T., Tekguler A., The effects of different maturity times of fruit ripening and limb connection heights on the percentages of fruit removal in mechanical harvesting of hazelnut (Cv. Yomra), Tarım Bilimleri Dergis Journal of Agricultural Sciences 20 (2014) 38-47.

[45] Senter S.D., Horvat R.J., Forbus W.R., Relation between phenolic acid content and stability of pecans in accelerated storage, J. Food Sci. 45 (1980) 1380-1392.

[46] Andreoni N., Hazelnut phenolic substances as natural antioxidants, Acta Hortic. 445 (1997) 217-222. 